\title{
Property Rights Theory, Transaction Costs Theory, and Agency Theory: An Organizational Economics Approach to Strategic Management
}

\author{
Jongwook Kim ${ }^{\mathrm{a}, *}$ and Joseph T. Mahoney ${ }^{\mathrm{b}}$ \\ ${ }^{a}$ Western Washington University, Bellingham, USA \\ ${ }^{\mathrm{b}}$ University of Illinois at Urbana-Champaign, Champaign, USA
}

\begin{abstract}
Property rights theory has common antecedents with contractual theories of the firm such as transaction costs and agency theories, and is yet distinct from these theories. We illustrate fundamental theoretical principles derived from these three theories by analyzing the business case of oil field unitization. Theoretical principles and application of theory to oil field unitization are each summarized. From this, it is possible to see how property rights theory is well suited to explain business situations where inefficient economic outcomes persist. Additionally, property rights theory forges new theoretical connections with other branches of organizational economics, in particular, resource-based theory. Copyright (C) 2005 John Wiley \& Sons, Ltd.
\end{abstract}

\section{INTRODUCTION}

Property rights theory has common intellectual antecedents with transaction costs theory and agency theory that have traditionally been applied to an organizational economics approach to the discipline of strategic management (Barney and Ouchi, 1986). Williamson's (1985, p. 24) 'cognitive map of contract' places each of these theories in the efficiency branch of organizational economics (see Figure 1 below). A common thread woven through these theories is dissatisfaction with neoclassical economics' treatment of firm behavior. This dissatisfaction has been channeled productively in the development of organizational economics theory within strategic management to

\footnotetext{
*Correspondence to: Western Washington University, College of Business and Economics, Management Department, 351 Parks Hall, 516 High Street, Bellingham, WA 98225, USA. E-mail: jongwook.kim@wwu.edu
}

explain and provide predictions for important business phenomena such as vertical integration (Mahoney, 1992b) and corporate diversification strategy (Teece, 1982).

Transaction costs theory has wide application in the social sciences, including economics, finance, marketing, organization theory, political science, sociology, and strategic management (Carroll et al., 1999), while agency theory has been usefully applied to issues in accounting, economics, finance, marketing, political science, and strategic management (Eisenhardt, 1989). These organizational economics theories form part of the theoretical core of the discipline of strategic management (Barney and Ouchi, 1986; Rumelt et al., 1994). However, property rights theory has received relatively little theoretical or empirical attention by strategic management researchers ${ }^{1}$ despite its potential to add substantial value in explaining and predicting various business phenomena (e.g. business decisions concerning 


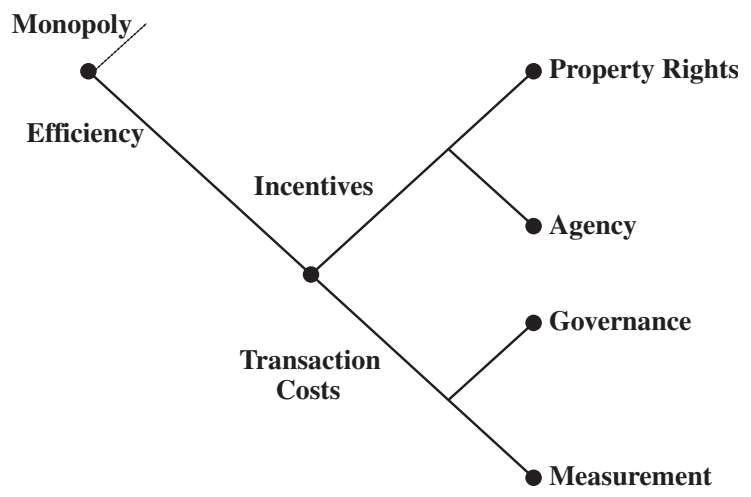

Figure 1. Williamson's 'cognitive map of contract': The efficiency side. Reprinted with the permission of The Free Press, a Division of Simon \& Schuster Adult Publishing Group, from The Economics Institutions of Capitalism by Oliver E. Williamson. Copyright (C) 1985 by Oliver E. Williamson. All rights reserved.

knowledge-based resources and intellectual property rights). The objectives of the current paper are to analyze extant property rights theory and to connect property rights theory to more mainstream strategic management perspectives of transaction costs theory and agency theory. We then illustrate fundamental theoretical principles derived from these three organizational economic theories (Barney and Ouchi, 1986) by analyzing the business case of (the contractual difficulties of achieving) oil field unitization in the United States.

Theories of property rights and asset ownership have gained wider intellectual currency in the economics discipline in recent years, following the seminal works of Grossman and Hart (1986) and Hart and Moore (1990). We refer to this stream of research literature as the 'modern property rights theory' (also sometimes called the 'GHM model') ${ }^{2}$ to distinguish from the stream of property rights literature that began with the earlier classical works of Coase (1959, 1960), Alchian (1965, 1969), Demsetz (1964, 1966, 1967), Alchian and Demsetz (1972, 1973), Cheung (1968, 1969, 1970), and Furubotn and Pejovich (1972, 1973, 1974), among others. More recent theoretical and empirical contributions to this earlier stream of research literature, which we refer to as the 'classical property rights theory' (to contrast with modern property rights theory), have been made by North (1981, 1990), Barzel (1982, 1997), Cheung (1983), Libecap (1989), Eggertsson (1990), and Alston et al. (1996), among others.
The early works of Coase, Alchian, and Demsetz formed the foundations for not only the two streams of property rights theories we cite here, but also for transaction costs theory (Williamson, 1975, 1985) and agency theory (Jensen and Meckling, 1976; Holmstrom, 1979; Fama, 1980; Fama and Jensen, 1983). The distinction between the 'classical' and 'modern' theories of property rights is analogous to Jensen's (1983) distinction between positive agency theory (Fama, 1980) and principal-agent models (Holmstrom, 1982). The 'classical' form of property rights theory provides greater attention to the historical and institutional context that shapes and changes property rights (and therefore led to 'getting the incentives right'). The 'modern' version of property rights theory, utilizing advanced mathematical tools, attempts stylized modeling of ownership and incentive structures.

The purpose of the current paper is to contribute to a better understanding of property rights theory, and to explain how property rights theory can be applied to strategic management theory and business phenomena. Here we provide a roadmap for the remainder of the current paper. First, an overview of property rights theory-its origins and recent theoretical extensions-is offered. Beginning with Coase's $(1937,1960)$ seminal contributions to what is now widely referred to as organizational economics (Barney and Ouchi, 1986), much of the early literature (e.g. Alchian, 1965; Demsetz, 1967; Furubotn and Pejovich, 1972) deals with fairly broad social science issues of economic development and social welfare. More recent studies by North (1990) and Libecap (1986, 1989) deal with the interface of economics and political science. Barzel (1997) and Cheung (1970) are exemplars in discussing property rights issues at a level of analysis closer to the individual firm context. The stylized analytic models of Grossman and Hart (1986) and Hart and Moore (1990) also deal with issues at the individual firm level.

Second, we discuss contributions that property rights theory can make to agency and transaction costs theories. Property rights theory is one branch of organizational economics, along with transaction costs theory, agency theory, and resourcebased theory (Barney and Ouchi, 1986; Mahoney, 1992a). Moreover, property rights theory can be viewed through the lenses of related theoretical frameworks, yet it has its own distinct perspective, and thus is complementary to these more 
established theories in strategic management. Indeed, some of the theoretical underpinnings of transaction costs theory and agency theory (and to a lesser extent, resource-based theory) ${ }^{3}$ are rooted in property rights theory.

Third, we consider some potentially fruitful topics and relevant business phenomena for research in strategic management using property rights theory. For instance, theories of institutional change at a macro-level can be applied to a more micro-level setting. One example of institutional change at the organizational level is Argyres and Liebeskind's (1998) property rights study of the commercialization of biotechnology. Also, in discussions of firm boundaries, it is perhaps widely accepted that neither transaction costs theory nor agency theory does a completely satisfactory job in explaining such ownership structures as joint ventures (and/or alliances). Property rights theory, particularly the 'classical' literature following Coase (1960), Alchian (1965) and Demsetz (1967), is thus complementary to extant organizational economics literature in strategic management because it suggests concepts of shared ownership and multi-dimensional definitions of property rights and ownership that can improve our ability to explain business phenomena that are neither market nor hierarchy, such as joint ventures (Hennart, 1993). Furthermore, property rights theory is well suited for explaining institutional change. Indeed, property rights theory is at the interface of law, economics and organization theory (Williamson, 1996), with (resource-based) business implications for the strategic management issue of appropriation (Liebeskind, 1996). The next section provides an overview of the property rights literature.

\section{OVERVIEW OF PROPERTY RIGHTS THEORY}

\section{Origins: Early Literature}

For the present purpose of analyzing property rights theory within the context of strategic management, we take Coase $(1937,1959,1960)$ as the conceptual starting point. Neoclassical economic theory portrays the market as an economic system where the price mechanism, Adam Smith's 'invisible hand,' efficiently and costlessly coordinates economic activities. Thus, resources are put to their most productive uses, and thereby the market arrives at an optimal output level (a Pareto optimal outcome). In the world of neoclassical economics theory, the existence of the firm is a paradox, since there is no compelling reason for the firm to exist if it is posited that markets function flawlessly and costlessly to reach an optimal output level (Coase, 1937). The economic reason the firm exists as a viable alternative to the price mechanism, of course, is because the price mechanism does not function flawlessly and costlessly.

There are strong parallels between Coase's 'Nature of the Firm' (1937) transaction costs paper and his 'Social Cost' (1960) property rights paper. In the 'Nature of the Firm,' because of the costs of operating the market (i.e. positive transaction costs), there are alternative modes of transacting (e.g. the firm). In the 'Social Cost' paper, (both positive and negative) externalities impede efficient market transacting, with the theoretical emphasis placed on how difficulties in perfectly delineating private property rights (i.e. positive transaction costs) imply different contracting outcomes (i.e. alternative allocative and distributive property rights outcomes). Therefore, the theoretical insight that is common to both Coase (1937) and Coase (1960) is that in a world of positive transactions costs a comparative assessment of different modes of organizing economic activities is needed. Or put differently, in a world of positive transaction costs, governance structures matter for efficiency outcomes according to transaction costs theory (Coase, 1937) and legal rules matter for efficiency outcomes according to property rights theory (Coase, 1960). Following Coase's seminal works, a comparative economic approach has been incorporated into subsequent theoretical and empirical developments in property rights theory (Demsetz, 1967, 1969, 1988) and transaction costs theory (Williamson, 1975, 1985, 1996).

Another important theoretical point in Coase (1960) and emphasized subsequently in Alchian (1965), Demsetz (1967), and Davis and North (1971), among others, is the dynamic (evolutionary) nature of institutional responses to new contracting situations. Early property rights scholars have argued that economic institutions tend to move toward more efficient economic solutions through negotiations between the interested contractual parties. In a world of zero transaction 
costs, this economic process would be immediate and efficient. However, if transaction costs are positive and non-negligible, this economic process may be more gradual, and in some economic cases may result in failure to reach contractual agreement (North, 1990). Often, vested interests and existing political, social, and economic positions of contracting parties lead to inefficient economic outcomes (Libecap, 1989; Alston et al., 1999). Indeed, North (1990) argues that no student of economic history can deny that efficient economic outcomes are the exception, rather than the rule.

To sum up, an important insight of property rights theory is that different specifications of property rights arise in response to the economic problem of allocating scarce resources, and the prevailing specification of property rights affects economic behavior and economic outcomes (Coase, 1960; Pejovich, 1982, 1995). A comparative institutional assessment of the economic costs and benefits of each specification of property rights is needed (Coase, 1960). Property rights theory also provides us with an evolutionary perspective (Anderson and Hill, 1975; Libecap, 1989; North, 1990) of the processes through which institutional choices are made, where the vested economic interests of contracting parties and potential distributional conflicts are taken into account and help in explaining why inefficient property rights regimes can persist.

\section{Key Ideas in Property Rights Theory}

Property rights define the nature of sanctioned human behavior (norms of behavior) (Furubotn and Pejovich, 1972). Such sanctioned behaviors allow people the right to use resources within the 'class of nonprohibited uses' (Alchian, 1965). Property rights are ' $[\mathrm{t}]$ he rights of individuals to the use of resources... supported by the force of etiquette, social custom, ostracism, and formal legally enacted laws supported by the states' power of violence or punishment' (Alchian, 1965, p. 129). This definition of property rights is conceptually broad and emphasizes the legal aspect of property rights as well as the social conventions that govern (business) behavior, such as corporate culture and reputation (Kreps, 1990). Barzel (1997) distinguishes economic concepts of property rights from legal concepts of property rights, viewing the more relevant concept of property rights to be the economic rights. We attempt a balanced theore- tical approach in considering the economic aspects of property rights as a complementary concept within the legal framework that allows such property rights legal protection and third-party enforcement.

All economic activities including trade and production are the exchange of bundles of property rights (Furubotn and Pejovich, 1972). Property rights are the rights to use, to earn income from, and to transfer or exchange the assets and resources (Libecap, 1989). Conceptualizing property rights to have multiple dimensions has the important economic implication of many different people being able to hold partitions of rights to particular facets of a single resource. That is, there is shared ownership. Consider a plot of land. One person may have the right to graze his livestock on it, while another may have the right to walk across it, and still another may have the right to fly an airplane over it, and so on. Here, different individuals may hold property rights to various partitioned uses of a plot of land. When more than two contracting parties can affect the income flow from a set of property rights, delineating each party's respective property rights becomes difficult. The critical economic issue of distribution of income that is generated by the collective efforts of different contracting parties (i.e. team production) needs consideration. Not only will the initial assignment of property rights impact the individual efforts of contracting parties, but the expected distribution will also impact those individuals participating in collective effort (Libecap, 1989; Kim and Mahoney, 2002).

Economic logic drives the demarcated uses of a resource to be partitioned among several parties, and in such a way that those partitions of rights can be aggregated into bundles of property rights (Alchian, 1965; Alchian and Demsetz, 1973). In particular, a configuration of property rights (e.g. an institutional arrangement) that is formed is posited to be an economically efficient response to a contractual situation. By economically efficient, a standard property rights definition applies where the partitions of property rights are grouped into appropriate bundles and assigned to the transacting party who is most capable of efficient production (utilizing that bundle), and the property rights that compose those bundles will be grouped so that appropriate economic incentives are created for owners of each bundle of property rights. 
The convergence to an optimal institutional arrangement is always attainable in the absence of transaction costs. Because of positive transaction costs, however, institutions that optimally suit the given contractual situation only gradually emerge, at best. Partitioning of property rights is the economic principle that drives the various applications of property rights theory. In any kind of institutional arrangement where more than two contracting parties are involved, resource owners must transfer to another transacting party the control over some attributes of a resource. This transfer of control is the very definition of a transaction: reallocating rights among transacting parties (Barzel, 1997). Various institutional and/or contractual arrangements attempt to allocate property rights to multiple contracting parties in an economically efficient way.

\section{A Digression on Recent Extensions of Property Rights Theory: The GHM Model}

Recent interest in property rights theory can be attributed to the highly influential published papers of Grossman and Hart (1986) and Hart and Moore (1990). Using a stylized mathematical approach, the stream of research literature that began with these two seminal papers (hence the acronym, 'GHM model') asks the strategic question of who should own what assets. In the GHM model, because of potential contractual hazards (e.g. ex post opportunism) due to relation-specificity between separately owned assets, the residual control rights to these assets that make up a particular bundle of relation-specific assets ${ }^{4}$ must be concentrated in one contracting party (i.e. common ownership). The contractual party that retains ownership is the party that has the most to gain from this bundling of relation-specific assets. In these stylized models, rights to residual control over assets (and rights to residual returns) are equated with asset ownership that subsequently safeguards contracting parties from contractual hazards such as ex post holdup problems. Control rights are emphasized more than rights to residual returns (Hart, 1995) since control rights allow the owner of the right to use the asset in any way, as long as specified obligations (in addition to the social and legal norms) are satisfied. Whereas the GHM model equates ownership with residual control rights, classical property rights theory, particularly Alchian and Demsetz (1972), define ownership as residual rights to income. Hart (1995) explains that control rights are not divisible while residual rights to income are, and therefore, residual control rights are a stronger concept as a definition of ownership. However, the conceptualization of ownership as residual control does not resolve an important problem that Alchian and Demsetz (1972) put forth: Who will monitor the monitor? To put it differently, to equate ownership only with residual control rights is to ignore economic cases where there is separation of ownership and control. An agent can appropriate a principal's ownership rights by shirking in circumstances where information asymmetry and measurement problems exist.

If contracts were complete (as agency-theoretic models typically assume) then ownership would not matter for economic efficiency, since each contingency would be specified in the contract (i.e. there are no residual rights, by definition). Thus, ownership is simply not an issue in the agency framework. But due to bounded rationality most contracts are incomplete (Hart, 1988) as transaction costs theory emphasizes (Williamson, 1985). The incompleteness of contracts means that there are non-contractible elements due to difficulties in contemplating in advance all possible future contingencies and measuring performance under each contingency. Because of this unspecified portion of the contract, there are potential economic problems in the sharing of joint output between contracting parties, and hence incentive problems in investing (up-front) in relation-specific assets (Grossman and Hart, 1986). ${ }^{5}$

Grossman and Hart (1986) and Hart and Moore (1990) contribute to incomplete contracting theory (i.e. property rights theory and transaction costs theory) by clarifying the meaning of integration (common asset ownership), and by demonstrating why contractual (transaction costs) problems might exist in the absence of common ownership. More generally, the modern property rights theory complements extant agency theory and transaction costs theory by introducing ownership concepts in an incomplete contract setting, and emphasizing relation-specific assets (both physical and human asset specificity). However, the modern property rights theory is not an unambiguous scientific advance over classical property rights theories (Demsetz, 1998; Foss and Foss, 1999, 2001).

Demsetz (1998) criticizes the GHM model for its ambiguous conception of ownership. The notion 
of residual (control) rights being equated with ownership is tenuous as residual rights themselves are by definition difficult to specify precisely. Yet the GHM model anticipates that courts will uphold ownership claims based on residual rights of control. Indeed, as a matter of convenience and practicality, ownership would be recognized as belonging to the right-holders with the most 'important' portion of the bundle of rights, which would not necessarily be the residual rights (Demsetz, 1998). Similarly, Foss and Foss (1999) note that there is a logical inconsistency of ownership (i.e. residual rights of control) being fully enforceable in court, while contracts are incomplete (i.e. not enforceable in court) due to difficulties of anticipating and writing contracts that specify all contingencies and due to difficulties of measuring and verifying performance under each contingency.

It is our argument that much of this ambiguity and logical inconsistency in the GHM model can be traced to its simple, uni-dimensional conception of property rights (ownership rights) to assets, perhaps necessitated by the practical limitations of analytical modeling. As we elaborate in a later section, ownership of an asset is not ownership of the physical entity itself, but ownership of specific property rights to an asset (or certain aspects of an asset) (Coase, 1960). Ownership can be shared, and property rights (to the same asset) that are owned by different contracting parties are interdependent. Although Grossman and Hart (1986) note that in reality asset ownership is obviously far more complex than what their model describes, by equating ownership with residual control rights, shared ownership of an asset is precluded altogether since residual control rights cannot be divided.

An example of shared ownership is the joint venture, where two or more independent firms pool resources into a separate legal entity. In particular, if the joint venture takes the form of an equal equity (e.g. 50-50 stake) joint venture, with each parent firm investing critical elements into the venture (say firm $A$ invests in $R \& D$ and firm $B$ invests in manufacturing and marketing, which are assumed to be separate activities, independent of each other), it is clear firm A should control the assets critical to $R \& D$ operations and firm $B$ should control the assets critical to manufacturing and marketing operations. What is not clear is to what extent should the partner firms share in, for instance, the unanticipated gains of the joint venture if one of the firms in the joint venture finds a new commercial use from the by-product of the joint venture for one of its own products. How much of the economic benefits from that new finding should the other firm be entitled to?

One of the great insights of Coase (1960) was to understand that such externalities as described above arise because boundaries of property rights are unclear (i.e. imperfect delineations of property rights imply positive transaction costs). A more comprehensive theory of property rights must take into account the interdependent nature of property rights. Or put differently, a more comprehensive theory of property rights must take into account ex post transaction costs. Assumptions that courts perfectly enforce contracts are neither satisfactory in practice nor satisfactory in theory (i.e. there are logical inconsistencies as discussed above).

Another critical theoretical point that has been overlooked in the GHM model is that other contracting parties can appropriate even nonresidual (i.e. well-specified) rights (Foss and Foss, 1999). Even if all the non-residual (specified) rights are clearly defined and effectively enforced, so that the portion of contract that is non-residual resides in the economic world of complete contracting, there is still the matter of asymmetric information leading to measurement costs (Barzel, 1982) (which still applies even in a world of complete contracting).

Consider rental contracts. Even where the rights of the renter can be perfectly specified in advance, if the costs of monitoring compliance (asymmetric information) and measuring the degree of that compliance (measurement costs) are significant, the renter will be able to appropriate some economic benefits from the contractual relationship despite perfect specification of property rights. In sum, for a comprehensive concept of property rights that reflects the classical property rights theory (Coase, 1960; Alchian, 1965; Demsetz, 1967; among others), we must additionally consider that (1) there can be multiple partitions of property rights to any particular asset (i.e. assets have multiple attributes), and (2) even non-residual rights can be appropriated (i.e. they are not perfectly secure).

Now that property rights theory has been analyzed, we next turn toward comparing property rights theory with transaction costs theory and agency theory (that form the core of what Barney 
and Ouchi (1986) refer to as 'organizational economics').

\section{COMPARING PROPERTY RIGHTS THEORY WITH AGENCY THEORY AND TRANSACTION COSTS THEORY}

In this section, we analyze how property rights theory fits conceptually into the overall context of organizational economics (Barney and Ouchi, 1986; Mahoney, 1992a). In particular, we compare property rights theory with agency theory and transaction costs theory, and we illustrate theoretical principles using the business case of oil field unitization because case analysis breathes some life into these otherwise abstract theoretical principles. Moreover, the oil field unitization case illustrates well a contracting situation where the bargaining parties are confronted with severe information asymmetry in determining the sharing rules, often resulting in sub-optimal contracting outcomes (i.e. 'contracting failures').

\section{Oil Field Unitization}

Oil field unitization occurs when a single firm is designated as the unit operator to develop the oil reservoir as a whole. Unitization is economically desirable because with a single unit operator, there are incentives to develop the reservoir to maximize aggregate value of the entire oil reservoir rather than separately maximizing production from each of the individual oil leases, as would be the case in individual drilling (i.e. each leaseholder drills competitively). This business case, where multiple contracting parties (i.e. oil firms who lease mineral rights from landowners) negotiate a sharing rule to consolidate their economic interests (i.e. 'unitize'), highlights different organizational economics aspects of contracting in property rights, agency, and transaction costs theories. Such an intellectual exercise hopefully will demonstrate the usefulness of an organizational economics approach to strategic management as it applies to the business case of oil field unitization in the United States.

In the United States, multiple owners often own land over subsurface oil reservoirs. Importantly, oil is migratory, ${ }^{6}$ meaning that it moves within the reservoir so that it is possible for one landowner to drill on his land and to extract oil that had been under a neighbor's land. Common law rule of capture allows landowners to drill a well on their land and drain oil (and gas) from their neighbors without economic liability (Smith, 1987; Lueck, 1995), as property rights to oil and gas are assigned only upon extraction. It is the joint condition of multiple landowners of the surface over an oil reservoir, the common law rule of capture, and the migratory nature of oil (McDonald, 1971) that leads to an inefficient (and path-dependent) economic outcome concerning contracting for oil field unitization.

Extraction of oil is expensive because crude oil is trapped in pore spaces of the rock with little compressibility so that compressed gas and water are needed to build up sufficient pressure to push gas and oil out to the surface. Efficient production requires that extraction not be too rapid so that early venting of the water and natural gas that are needed to drive oil to the surface is prevented (Libecap and Wiggins, 1984), and spacing and location of wells must be appropriately placed (dense spacing leads to inefficient production) to maintain necessary pressure (Weaver, 1986). Maintaining an appropriate level of reservoir pressure is crucial for efficient extraction (Tiratsoo, 1976). Since many different owners own oil fields, each owner will seek to maximize his or her own output, thus resulting in competitive drilling (a 'race to produce'). Accordingly, at any point in time, individual production decisions are made to enhance economic value of each individual lease rather than to maximize economic value of the overall reservoir. This competitive drilling goes against efficient extraction principles of carefully locating wells and maintaining extraction rates to optimize production. As firms compete for migratory oil and gas, these 'prisoners' dilemma' problems lead firms to dissipate reservoir economic rents with excessive capital, too rapid production, and lost total recovery of oil (Wiggins and Libecap, 1985; Libecap, 1998).

To prevent waste and to extract oil efficiently, the most complete economic solution available is oil field unitization (Libecap, 1998). ${ }^{7}$ Unitization refers to a private contractual arrangement to reduce economic losses associated with commonpool extraction. ${ }^{8}$ Joining different oil leases in the reservoir forms a unit, and that is significant because oil reservoirs are not (geologically) uniform, meaning different tracts of land yield different levels of output. Unitization is 
characterized by several important contracting specifications. The length of the contract is $10-20$ years long, which is close to the natural life of the oil field. Because unitization irrevocably changes the geological characteristics of the oil field, individual lease shares cannot be inferred from post-unitization production. The contract is a once-and-for-all contract, where the economic sharing rules have to be specified in advance, with no renegotiation possible. Drilling is delegated to a single operator who is one of the residual claimants to economic profits from the reservoir, whereby strategic intent shifts from maximization of economic value of an individual lease to maximization of economic value of the unit (Libecap, 1998). In order to align economic incentives of the operator with maximizing production of the unit as a whole, the oil firm that is appointed the (lone) operator is normally the firm that has the most to gain (and the most to lose). Thus, oil field unitization is the most straightforward economic solution to a serious common-pool problem in oil and gas production where there are potentially large economic efficiency losses. Table 1 summarizes some of the main features of oil field unitization.

Despite the potential for substantial economic value creation, the actual rate of oil field unitization is surprisingly low. Oil field unitization yields substantial increases in productive efficiency, but many economic aspects of the contracting situa- tion, for example, the length of the contract, onceand-for-all nature of the contract, site-specific investments, uncertainty about the behavior of contracting parties and of the risk involved in drilling for oil, and other such elements contribute to implementation difficulties in successful unitization contracting.

\section{Comparison of Theoretical Perspectives}

In this section we compare the perspectives of agency theory, transactions costs theory, and property rights theory using the business case of oil field unitization. Table 2 provides the general distinctions among the three theoretical perspectives while Table 3 applies these theoretical points to the unitization case in terms of (1) unit of analysis, (2) focal dimension, (3) focal cost concern, (4) contractual focus, (5) theoretical orientation, (6) strategic intent, and (7) sources of market frictions. We now discuss each of these theoretical points in order.

Unit of analysis. The unit of analysis in agency theory is the principal-agent contractual relationship. Unlike transaction costs theory, which considers the dimensions of the transaction itself, agency theory places greater conceptual emphasis on the economic incentives of the contracting parties (individuals) within the context of this principal-agent relationship. Agency theory would

\section{Table 1. Oil Field Unitization: Summary of Technical and Contractual Features}

Oil fields usually encompass lands of many different owners, so that there are multiple landowners with access to the oil field.

Oil is migratory: oil moves about within the reservoir so that one landowner can extract oil that is under another landowner's land.

Common law rule of capture: property rights to oil are recognized only upon extraction. Oil that had been under someone else's land can be extracted without liability.

If oil is extracted too quickly or if too many wells are set up on a given tract of land, the aggregate extraction of oil becomes inefficient.

Inefficient extraction leads to early depletion of oil field (depletion merely means it is uneconomical to extract oil): aggregate production of oil is decreased.

Oil fields are not uniform: due to structural (geological) heterogeneity, different tracts of land within the reservoir have inherently different output potentials.

Once-and-for-all contract: sharing rules have to be specified at the outset, and cannot be renegotiated (once-and-for-all). Unitization changes the geological characteristics of the land irrevocably so that one cannot infer economic value of a particular oil lease from post-unitization production.

10-20 years duration: unitization contracts last for most of the life of the oil field.

A single-unit operator is assigned to extract oil and distribute among the participants to unitization according to the predetermined sharing rules. Normally, the unit operator is the firm with the most to gain and the most to lose. 
Table 2. Comparison of Organization Economics Theories

\begin{tabular}{|c|c|c|c|}
\hline & Agency theory & Property rights theory & Transaction costs theory \\
\hline Unit of analysis & Principal-agent contract & Institution & Transaction \\
\hline Focal dimension & Incentives & Property rights & Various types of asset specificity \\
\hline Focal cost concern & Residual loss & $\begin{array}{l}\text { Externalities. } \\
\text { Rent-seeking }\end{array}$ & $\begin{array}{l}\text { Maladaptation. } \\
\text { Holdup problems }\end{array}$ \\
\hline Contractual focus & $\begin{array}{l}\text { Ex ante incentive alignment. } \\
\text { Monitoring mechanisms }\end{array}$ & $\begin{array}{l}\text { Ex ante property rights allocation } \\
\text { and ex post distributional conflicts }\end{array}$ & $\begin{array}{l}\text { Choice of (ex post) governance } \\
\text { mechanism }\end{array}$ \\
\hline $\begin{array}{l}\text { Theoretical orien- } \\
\text { tation }\end{array}$ & Constrained optimization & Comparative assessment & Comparative assessment \\
\hline Strategic intent & Shareholder view & Stakeholder view & Shareholder view \\
\hline $\begin{array}{l}\text { Sources of market } \\
\text { frictions }\end{array}$ & $\begin{array}{l}\text { Information asymmetry, unob- } \\
\text { servability, risk aversion (by } \\
\text { agents) }\end{array}$ & $\begin{array}{l}\text { Externalities, unclearly defined and } \\
\text { difficult to enforce property rights } \\
\text { (Weak appropriability), vested in- } \\
\text { terests }\end{array}$ & $\begin{array}{l}\text { Bounded rationality, uncertainty, } \\
\text { information asymmetry, opportu- } \\
\text { nism, and asset specificity }\end{array}$ \\
\hline
\end{tabular}

Table 3. Comparison of theories: application to oil field unitization case

\begin{tabular}{|c|c|c|c|}
\hline & Agency theory & Property rights theory & Transaction costs theory \\
\hline $\begin{array}{l}\text { Unit of } \\
\text { analysis }\end{array}$ & $\begin{array}{l}\text { Oil firms (principals) } \\
- \text { unit operator (agent) }\end{array}$ & $\begin{array}{l}\text { Unitization as an } \\
\text { institution (contracting for } \\
\text { unitization in general) }\end{array}$ & $\begin{array}{l}\text { Individual unitization } \\
\text { contractual transactions }\end{array}$ \\
\hline $\begin{array}{l}\text { Focal } \\
\text { dimension }\end{array}$ & $\begin{array}{l}\text { Incentives of unit operator } \\
\text { (agent) may diverge from } \\
\text { other oil firms (principals) }\end{array}$ & $\begin{array}{l}\text { Property rights to oil are } \\
\text { not secure (a common- } \\
\text { pool resource) }\end{array}$ & $\begin{array}{l}\text { Interdependence of oil } \\
\text { leases (asset specificity) }\end{array}$ \\
\hline $\begin{array}{l}\text { Focal cost } \\
\text { concern }\end{array}$ & $\begin{array}{l}\text { Given unitization, cost of } \\
\text { monitoring unit operator, } \\
\text { residual loss from } \\
\text { imperfect incentive } \\
\text { alignment }\end{array}$ & $\begin{array}{l}\text { Negative externalities } \\
\text { (competitive drilling) } \\
\text { Rent-seeking (to influence } \\
\text { public policy) }\end{array}$ & $\begin{array}{l}\text { Maladaptation costs } \\
\text { Potential (strategic) } \\
\text { holdout }\end{array}$ \\
\hline $\begin{array}{l}\text { Contractual } \\
\text { focus }\end{array}$ & $\begin{array}{l}\text { Ex ante incentive } \\
\text { alignment: assign party } \\
\text { with largest residual claim } \\
\text { as unit operator, and } \\
\text { implement monitoring } \\
\text { mechanisms }\end{array}$ & $\begin{array}{l}\text { Maximize welfare (joint } \\
\text { profit maximization) } \\
\text { Common pool resource } \\
\text { problem: individual } \\
\text { rationality diverges from } \\
\text { collective rationality. }\end{array}$ & $\begin{array}{l}\text { Choice of efficient } \\
\text { governance mode } \\
\text { (once unitization occurs, } \\
\text { hierarchy-like coordinating } \\
\text { mechanisms take over) }\end{array}$ \\
\hline $\begin{array}{l}\text { Theoretical } \\
\text { orientation }\end{array}$ & $\begin{array}{l}\text { Theory of second-best } \\
\text { Optimal contract within } \\
\text { constraints such as } \\
\text { information asymmetry, } \\
\text { and non-observability }\end{array}$ & $\begin{array}{l}\text { Comparative assessment } \\
\text { (changes in real world } \\
\text { institutions; path- } \\
\text { dependence) }\end{array}$ & $\begin{array}{l}\text { Comparative assessment: } \\
\text { choice between (imperfect) } \\
\text { discrete structural forms }\end{array}$ \\
\hline $\begin{array}{l}\text { Strategic } \\
\text { intent }\end{array}$ & $\begin{array}{l}\text { Shareholder view } \\
\text { (maximize principals' } \\
\text { payoffs) }\end{array}$ & $\begin{array}{l}\text { Stakeholder view } \\
\text { (considers public policy, } \\
\text { Various interest groups, } \\
\text { contracting parties) }\end{array}$ & $\begin{array}{l}\text { Shareholder view } \\
\text { (Minimize transaction } \\
\text { costs in order to create } \\
\text { shareholder value) }\end{array}$ \\
\hline $\begin{array}{l}\text { Sources of } \\
\text { market } \\
\text { frictions }\end{array}$ & $\begin{array}{l}\text { Imperfect } \\
\text { observability }\end{array}$ & $\begin{array}{l}\text { Property rights to oil are } \\
\text { not secure (rule of capture; } \\
\text { appropriation is possible) } \\
\text { Interdependent tracts } \\
\text { (externalities) } \\
\text { Information asymmetry } \\
\text { (evaluating sharing rules) } \\
\text { Vested interests }\end{array}$ & $\begin{array}{l}\text { Information asymmetry in } \\
\text { evaluating productivity of } \\
\text { tracts of land } \\
\text { Asset specificity } \\
\text { (interdependent tracts of } \\
\text { land) exacerbates } \\
\text { information asymmetry }\end{array}$ \\
\hline
\end{tabular}


interpret this business case from the economic perspective of the individual oil firm. The key productive resources are the oil leases (oil-producing tracts of land) and not the drilling capabilities of oil firms (leaseholders), which are assumed to be homogeneous across different oil firms. Alchian and Demsetz (1972) suggest that given the freerider problems inherent in team production where each team member's actions are non-observable and/or are difficult to measure, a party central to all contracts is needed as the monitor to ensure each party's compliance with the contractual stipulations. But because the nature of oil field contracting makes it difficult to detect defection, rather than attempting to monitor compliance by each individual contracting party, oil field unitization centralizes the extraction activity to a single unit operator. Therefore, the principals would be the oil firms (including the unit operator) while the unit operator is the (lone) agent. Another important point to note is that an agency theory analysis of this particular case of oil field unitization would look at how the principal-agent relationship is managed once this relationship is established. If there are economic benefits to team production (e.g. with unitization) then, under agency theory, there is no reason for the unitization to not be put into place.

The unit of analysis under transaction costs theory is the transaction, i.e. the unitization contract. Transaction costs theory explains the choice of organizational form as matching transactions that have certain transactional characteristics with the appropriate governance mechanisms (Hennart, 1993; Williamson, 1996). The strong interdependence between the different tracts of land, whereby one oil firm (leaseholder) can extract oil from his lease and impact the extraction output of another oil firm within the reservoir would be, in transaction cost terms, asset specificity. High asset specificity necessitates, under transaction costs logic, integration of these idiosyncratic assets and coordination by the hierarchy mechanism as the more efficient organizational form to mitigate transaction costs of maladaptation. ${ }^{9}$

The main concern of property rights theory, beginning with Coase (1960), has been social welfare, and with regard to unitization, the main concern is with inefficiency (dead-weight social loss) at an overall economy level and its implications for public policy and the legal framework. The unit of analysis is the unitization contract, and not only is the individual unitization contract considered, but the viability of the institution of unitization is considered as well. Because property rights theory focuses on the institution of unitization, the political environment and analysis of public policy regarding unitization are considered in addition to the unitization contract at a micro-analytic level (i.e. various dimensions of the transaction and within the context of principal-agent relationships). Indeed, one of the empirical findings of property rights analysis in oil field unitization in the United States is that the various elements that lead to widespread contractual failure have far-reaching implications for some of the reasons why the government is also ineffective in resolving economic inefficiencies (Libecap and Wiggins, 1985; Kim and Mahoney, 2002). Not only will people pursue their self-interest within the rules, they will also allocate resources toward changing (or maintaining) property rights rules to their own benefit (Goldberg, 1974; Miller, 1992). In fact, it should be noted that agency theory, property rights theory, and transaction costs theory can all be usefully applied to explain economic cooperation among oil firms within an oil reservoir. Relative to transaction costs and agency theory (especially mathematical principal-agent models), property rights theory takes a more dynamic (evolutionary) view of the contract (Kim and Mahoney, 2002).

Focal dimensions/cost concerns. Agency theory concentrates on the economic incentives of individuals (in this case, individual oil firms), particularly on how to align the economic incentives of the agent with those of the principal in order to maximize aggregate economic payoffs (for the principal). Absent unitization (i.e. if there is competitive drilling), the incentives of each oil firm are to maximize the economic value of their own oil lease. But with unitization, all the oil firms stand to gain significantly in terms of productivity increase when the output of the unit as a whole is maximized. That is, there is great potential for aggregate economic gains from team production (i.e. unitization), but as is often the case in team production settings, agency problems exist. In agency theory, the focal point is to have the highpowered market incentives of individuals channeled to productive uses, by aligning those economic incentives with the overall goals (i.e. maximization of unit production), and monitoring the behavior of the agents, and thereby minimizing residual economic loss via ex ante contractual design. 
The agency relationship in unitization is between the oil firms (principals) and the lone unit operator (agent). Monitoring exists in the form of various governance mechanisms such as voting rules, notification requirements, grievance and arbitration procedures, unit operator reporting and accounting practices, and supervisory committee, among others (Libecap and Smith, 1999, 2001). Even with all of these monitoring mechanisms in place, there is still residual economic loss due to misalignment of economic incentives (because monitoring is costly).

Transaction costs theory is more explicit about the possibility of inefficient economic outcomes. Unlike agency theory, an important premise of transaction costs theory is that incentives in hierarchies are qualitatively different from market incentives, and can encourage economic cooperation in situations where purely high-powered market incentives would result in inefficient economic results (i.e. there is a relative economic efficiency of hierarchy over market). Potential contracting problems are acute where there is asset specificity involved, as there are potential holdup problems (opportunism). In the oil field unitization case, forming a unit and assigning all production to a single unit operator with economic sharing rules specified in advance effectively eliminates the holdup problem. By forming a unit, the asset specificity problem is mitigated because interdependent assets are consolidated into one asset (i.e. the oil field is 'unitized'). However, interdependence between assets does play an important economic role in agreeing on (or, failing to agree on) the economic sharing rules. In effect, although holdup is precluded in the case of oil field unitization, the oil firms that transaction costs theory would predict to have an economic incentive to engage in holdup would likely engage in other activities to extract the appropriable quasi-rents that it could have gained had holdup been a viable option: hence, the potential 'holdout' problem.

Property rights theory views the problem of interdependence of production activities between oil leases in more general terms, as a potential externality problem. By competitively drilling on one's own lease (i.e. maximizing oil production of a lease), that oil firm can negatively impact other firms' production levels. Externalities come about because property rights are insecure (i.e. can be appropriated) and/or are inefficiently assigned.
Common law rule of capture allows oil firms to drill on their own leases even if they were to drain oil that had resided under a neighbor's lease (at least to the extent the geological nature of the oil field allows), resulting in a common-pool resource problem. One oil firm's drilling activities will have an impact (an instance of negative externality) on the productivity of another oil firm's drilling activities. Because the property rights to oil are not secure (only the mineral rights to a tract of land are secure), there is an ensuing struggle to capture the economic rents, often leading to mutually damaging economic results where the potential increase in aggregate production from unitization is foregone.

Looking beyond agency and transaction cost perspectives, an additional insight of property rights theory is that profit-maximizing incentives of individual oil firms, including potential holdout motives, lead to inflexible economic and political positions, making contracting difficult. This economic outcome is a case of where vested economic interests make it especially difficult for successful contracting if the number of contracting parties is large and/or the characteristics of the contracting parties are heterogeneous (Libecap, 1989). ${ }^{10}$ In the oil field unitization case, the number of independently owned tracts of land on an oil field is large, sometimes in the range of hundreds of different owners. And there is also some degree of heterogeneity, as the economic incentives of large and small firms differ, for example, making any form of consensus with regard to unitization difficult. The economic incentives that lead to competitive drilling also carry over to rent-seeking behaviors via substantial political activities that try to influence the regulations and statutes concerning oil field unitization.

Contractual focus/theoretical orientation. Agency theory focuses on the ex ante alignment of economic incentives. Because agency theory works out of a complete contracting setup, getting the economic incentives right at the outset leads to efficient contracting (since ex post enforcement problems are assumed to be non-existent in agency theory). Assigning as unit operator the oil firm with the largest (potential) claim to residual income is the best way to minimize agency costs. Agency costs are comprised of '(1) the monitoring expenditures of the principal, (2) the bonding expenditures by the agent, and (3) the residual loss,' (Jensen and Meckling, 1976, p. 308). The first 
two categories of economic costs, monitoring and bonding expenditures, are incurred to restore residual loss to pre-dilution of ownership (before separation of ownership and control) level of agency costs (Williamson, 1996). The theoretical orientation of agency theory is to design contracts that minimize agency costs, given various constraints. Thus, in the case of oil field unitization, an application of agency theory would be in designing the optimal mix of governance mechanisms that would align the economic incentives of the unit operator with the rest of the residual claimants (remaining leaseholders with a stake in the oil reservoir). Assigning the largest leaseholder (the leaseholder with the most to gain and lose from unitization) as unit operator would be an efficient starting point in assigning economic incentives that would help to minimize monitoring and bonding costs.

Transaction costs theory assumes an incomplete contract setting, unlike agency theory. Because contracts are incomplete, transaction costs theory focuses on ex post transaction costs: '(1) the maladaptation costs incurred when transactions drift out of alignment, ... (2) the haggling costs incurred if bilateral efforts are made to correct ex post misalignments, (3) the setup and running costs associated with the governance structures (often not the courts) to which disputes are referred, and (4) the bonding costs of effecting secure commitments' (Williamson, 1996, p. 176). In transaction costs theory, unlike in agency theory, getting the economic incentives right at the outset of the contract does not guarantee the optimal unitization contract. The governance choice is not an optimal mix of monitoring and enforcement mechanisms, but the better governance choice among (imperfect) available alternatives of bundles of monitoring and enforcement mechanisms (discrete structural forms; Williamson, 1991). In this way, transaction costs theory takes a more holistic view of governance choice that entails both ex ante and ex post features (whereas ex post problems are suppressed in agency costs). Of the available economic alternatives in extracting oil from oil fields, unitization is one of many potential solutions. Moreover, despite its value-enhancing characteristics, it is an imperfect alternative. The transfer of property rights (mineral rights) to a particular tract of land for 10-20 years (usually close to the natural duration of the oil field's life), and for all intents and purposes, is a terminal transfer, with the share of total production being the effective price of transfer. Coordination mechanisms of unitization are analogous, therefore, to hierarchy, and any conflicts or contractual issues that arise once oil field unitization takes place are handled accordingly (with various internal coordination mechanisms).

Property rights theory, like transaction costs theory, is also a comparative assessment framework. ${ }^{11}$ However, property rights theory focuses on improvements in social welfare (Coase, 1960), while transaction costs theory focuses on reducing costs (Coase, 1937). Under unitization, the property rights to drill the oil reservoir are assigned to the contracting party with the largest residual claim (the oil firm with the most to gain or lose is the firm with the largest residual claim). Similar to agency theory, given the once-and-for-all nature of the contract, it is important to assign property rights to drill oil from the reservoir as a whole to the firm chosen as the unit operator, in order to align incentives of the contracting parties.

Agency theory and transaction costs theory are concerned with minimizing the contractual problems that can occur in oil field unitization. However, neither theory deals with the question of whether unitization actually takes place (and if not, what impedes the transaction). A key distinction between the theories is that agency theory, and to a lesser extent transaction costs theory, assumes (long-run) equilibrium outcomes. Decision-makers are (given the various uncertainties) intendedly rational and show purposive behavior in undertaking conscious design of the firm's (or, contractual) structure and policies (Furubotn, 2001).

Moving beyond agency and transaction costs perspectives, property rights theory (e.g. Libecap, 1989; North, 1990; Eggertsson, 1990) brings elements into the analysis of contracts and of institutions that account for circumstances where there is potentially failure to reach satisfactory contractual agreements. An inefficient initial allocation of property right and path-dependence, even if decision-makers are intendedly rational, may result in fixed bargaining positions that are vastly divergent and hence difficult to reconcile, thus leading to persistent suboptimal contracting outcomes. Also making contracting difficult is the prisoners' dilemma-like situation where each contracting party drills his own lease competitively with strong market incentives making adherence to any kind of cooperative agreement difficult (e.g. much like maintaining and enforcing tacit 
collusion among oligopolists). In the particular instance of oil field unitization, information asymmetry and technical uncertainty make accurate economic valuations of individual leases difficult, and hence the wide difference between the estimation of each contracting party's initial resource allocation (what each contracting party claims is the accurate sharing rule) and the expected distribution of contractual outcome (proposed sharing rules of the unitization contract).

Strategic intent. Unlike agency theory and transaction costs theory, property rights theory (as explicated by Libecap, 1989; North, 1990) does not assume or predict efficient contracting to result even with long time horizons. Property rights theory gives greater attention to such elements as economic vested interests and the economic impact of distributional conflicts on the initial allocation of property rights. Many institutional details, as in the case of oil field unitization, ultimately contribute to contractual failure. For example, public policy elements (e.g. initial endowment of land to settlers, antitrust policy tradition, vote maximizing behavior of the legislature, etc.) and the efforts by various interest groups to exert influence not only in the contracting process itself, but also on public policy, serve as the rich institutional backdrop for analysis of contracting and persistently inefficient appropriability regimes (e.g. persistent resistance to oil field unitization in the United States).

Sources of market frictions. Property rights theory views the sources of imperfections in the market as unclearly defined and/or insecure property rights. Unclearly defined property rights are the rights that have not been assigned to the contractual party with the economic incentive and ability to maximize utilization of the resource, while insecure property rights are the rights that can be appropriated by others. In the case of oil field unitization, property rights to oil are not secure since oil must first be extracted (the rule of capture). The economic result is that the competing firms in the oil field will be generating negative externalities for each other by weakening the subterranean pressures necessary for economically efficient oil extraction. Such (negative) externalities result in inefficient economic contracting. Widespread contractual failure to achieve oil field unitization in the United States despite large potential aggregate economic gains shows how asymmetric information and distributional conflicts over rental shares can limit adoption of property rights that would enable the 'internalization of externalities' and thereby enhance economic value creation (Libecap, 1998; Kim and Mahoney, 2002). Or put differently, the case of the (lack of) oil field unitization in the United States illustrates how difficult it can be to get the institutional details of the property rights correct for realized value creation. In an economic world of positive transaction costs, there are frictions in the development of property rights that can drive a persistent wedge between potential value and realized value creation.

Negative externalities exist when one does not bear the full economic cost for his or her actions. Agents engage in activities that may not benefit the principals because they do not bear the full economic costs of their actions. Agency theory explains this potential economic outcome using the concepts of information asymmetry and nonobservability. In selecting a unit operator and to get the best effort from the unit operator, the other residual claimants need to align economic incentives and to implement appropriate monitoring mechanisms. For agency theory, because the analysis proceeds with unitization as a given and focuses on how the principal-agent relationship is managed within the context of unitization, the key source of market friction would arise from the imperfect observability of the (lone) unit operator (i.e. hidden action), hence the need for various governance mechanisms under unitization. Despite such efforts, there will be some residual economic loss due to information asymmetry and non-observability. The important economic issue of minimizing residual loss is further complicated by the differing risk attitudes of (risk-averse) agents and of (posited risk-neutral) principals.

Transaction costs theory adds a few more conceptual transaction characteristics, namely asset specificity and opportunism. Asset specificity captures the idea of generating (negative) externalities by each oil firm competitively drilling on its tract. Different tracts within an oil reservoir are interdependent and the action of one party has an economic impact on the other. Also, opportunism in the form of strategic holdout in forming a unit exists as well. Due to the non-uniformity within the oil reservoir, certain tracts have a structural advantage in extracting oil. Such tracts are often important for efficient economic extraction of the unit. Firms in such advantageous strategic positions will hold out until compensated sufficiently. 
To sum up, there are at least two noteworthy theoretical features here. First is that agency theory is not concerned with the process of how a unitization agreement actually comes about. That is, agency theory focuses on the principalagent relationship once a team production setting, with principal-agent relationship, is put in place. But why unitization (despite its potential for aggregate economic gain) is formed, or even more important, why it will not be formed, falls outside the analytical framework of agency theory. Second, both agency and transaction cost concepts of market frictions can be largely subsumed under the property rights concept of (negative) externalities. The final section below provides discussion and conclusions.

\section{DISCUSSION AND CONCLUSIONS}

What does property rights theory contribute to the explanation (and perhaps prediction) of various business phenomena that other contractual theories of the firm (i.e. agency theory and transaction costs theory) do not? As demonstrated in the oil field unitization case, these three organizational economics theories (Barney and Ouchi, 1986) highlight different contractual features of the business situation. Property rights theory more fully accounts for business cases where inefficient economic outcomes (contractual imperfections) persist, while transaction costs and (especially) agency theory take a more optimistic (equilibrium) perspective. Also, (classical) property rights theory is better equipped to handle strategic issues of shared ownership, such as joint ventures and alliances. Neither transaction costs theory nor agency theory is well equipped to deal with cases where the transacting parties fail to arrive at a contractual arrangement. Although agency theory differs from transaction costs theory (and from property rights theory) as it utilizes a 'complete contracting approach' that takes a constrained optimization perspective for finding the most efficient mix of governance mechanisms, both agency and transaction costs theories assume an equilibrium state for the chosen organizational outcome. To put it differently, within the constraints of various economic costs (i.e. agency costs and transaction costs), agency and transaction costs theories assume economic actors arrive at an efficient (equilibrium) outcome. Property rights theory sometimes leads to different predictions because this theory is more appreciative of vested interests and (landowners' single play) prisoners' dilemma problems that perpetuate inefficient economic outcomes.

Shared ownership is another instance where agency and transaction costs theories are not satisfactory. For example, joint ventures and alliances are mechanisms for shared ownership where appropriation of resources held in common by the participating firms is of much interest (e.g. learning races in strategic alliances). Agency theory does not view firms and markets as being different in a qualitative sense (thus Jensen and Meckling $(1976,1979)$ view the firm as a 'nexus of contracts'). And transaction costs theory views joint ventures as hybrids of market and hierarchy, characterized by 'intermediate' level of asset specificity (Williamson, 1996). Even Hart and Moore's (1990) property rights model has been criticized for not being able to deal with intermediate forms of ownership (e.g. joint ventures) (Holmstrom, 1999). To overcome this criticism, we submit that the property rights framework (of the GHM model) must correct the simplified notion of ownership employed (residual control rights are equated with ownership), leading to an approach where legal and economic concepts of property rights (Barzel, 1997) are better balanced. The property rights framework must also correct the lack of accounting for partitioning of ownership (multifaceted concept of property rights). The classical property rights theory of Coase (1959, 1960), Alchian (1965, 1969), Demsetz (1964, 1967), Cheung (1969, 1970), and Alchian and Demsetz (1972, 1973), among others, explains that asset ownership is a multidimensional concept since asset ownership is not equated with just one property right, but with a bundle of partitions of property rights. Furthermore, property rights are not always legally enforced but also can include various rights grounded in conventions, culture, relationships, and many other (sociological) elements.

Another potential strategic management application that might benefit from property rights theory (and in particular, a theory of commonpool resources) is to view brand name capital as a shared intangible resource in franchising. Franchisees benefit economically from a strong brand name, a brand name into which the franchiser has often made substantial investments, but do not 
bear the full economic costs of not upholding the quality standards implied by the strong brand name (Michael, 2000). This business context has the characteristics of a common-pool resource problem, with the economic value of the commonpool resource being dissipated through misuse (e.g. over-utilization).

Having the same antecedents as transaction costs and agency theories, and providing the theoretical background for these theories, property rights theory is a complementary organizational economics approach that informs analysis of both institutions and governance within the discipline of strategic management. Property rights theory suggests that two economic elements are critical for understanding ownership: residual control rights (Grossman and Hart, 1986; Hart and Moore, 1988,1990; Hart, 1995) and residual rights to income (residual claimancy) (Alchian and Demsetz, 1972). On the one hand, the appropriate allocation of residual control rights suggests mitigating ex post contractual problems, while on the other hand appropriately aligning residual claims leads to mitigating ex ante contractual problems. Both residual control and residual claimancy (ex ante and ex post contractual) issues are at the heart of a definition of ownership.

In conclusion, property rights theory has much to offer strategic management as a theoretical foundation for existing organizational economics theories and as a distinct approach for understanding new strategy phenomena. It enriches the organizational economics literature as the general theoretical form upon which both agency and transaction costs theory are grounded.

Just as property rights theory informs resourcebased theory by suggesting a clear theoretical base for conceptualizing resources and capabilities (Liebeskind, 1996; Kim and Mahoney, 2002), property rights theory provides the theoretical basis for conceptualizing organizational integration in terms of common ownership.

Property rights theory can improve our understanding of such business phenomena as vertical integration (Grossman and Hart, 1986), shared ownership (e.g. joint ventures and franchising) (Hennart, 1993), commercialization policy (Argyres and Liebeskind, 1998), the study of business culture (Jones, 1983), the value of knowledge and resources via patents, copyrights and trade secrets (Liebeskind, 1996; Miller and Shamsie, 1996), intellectual property protection in the structure of inter-firm alliances (Oxley, 1999), the structuring of exchanges in international collaborative ventures (Chi and Roehl, 1997), and value creation in transition economies (Braguinsky, 1999). We conjecture that with advances in coordination enabled by information technology, intellectual property rights research will be a growth industry for at least the next decade in the discipline of strategic management.

\section{Acknowledgements}

We thank Rajshree Agarwal, Ruth Aguilera, Tailan Chi, Glenn Hoetker, Sungmin Kim, Yong Li, James Mahoney, Rachel Yang, Thomas Roehl, and Matthew Liao-Troth for their insightful comments on the paper. The usual disclaimer applies.

\section{NOTES}

1. Notable exceptions include: Argyres and Liebeskind (1999), Barney and Ouchi (1986), Hennart (1993), Jones (1983), Liebeskind (1996), Miller and Shamsie (1996), Oxley (1999), and Teece (1986).

2. For extensions and criticisms of the GHM model see Aghion and Bolton (1992), Aghion et al. (1994), Aghion and Tirole (1994, 1997), Athey and Roberts (2001), Bajari and Tadelis (2001), Baker, Gibbons and Murphy (1994, 1999, 2001, 2002), Bakos and Nault (1997), Bernheim and Whinston (1998), Bolton and Scharfstein (1998), Bolton and Whinston (1993), Brynjolfsson (1994), Chiu (1998), De Meza and Lockwood (1998), Gibbons (1998), Grossman (2001), Hackett (1993), Hart and Moore (1999), Hellmann (1998), Holmstrom (1999), Holmstrom and Milgrom (1991, 1994), Holmstrom and Roberts (1998), James (2000), Jehiel and Moldovanu (1999), MacLeod and Malcomson (1993), Maskin and Moore (1999), Maskin and Tirole (1999a,b), Mullainathan and Scharfstein (2001), Muller and Warneryd (2001), Noldke and Schmidt (1995), Rajan and Zingales (1998, 2001), Segal (1999), Tirole (1999), Yang and $\mathrm{Ng}$ (1995), Whinston (2001) and Williamson (2000).

3. Seminal resource-based theoretical and empirical papers include: Afuah $(2000,2002)$, Amit and Schoemaker (1993), Argyres (1996), Barney (1986, 1991), Brush and Artz (1999), Chang (1996), Chatterjee and Wernerfelt (1991), Chi (1994), Coff (1997), Conner (1991), Dierickx and Cool (1989), Eisenhardt and Martin (2000), Eisenhardt and Schoonhoven (1996), Farjoun (1994, 1998), Foss (1996), Galunic and Eisnehardt (2001), Grant (1996), Helfat (1994, 1997), Helfat and Raubitschek (2000), Henderson (1994), Henderson and Cockburn (1994), Hoopes and Postrel (1999), Leonard-Barton (1992), Lippman and Rumelt (1982), Mahoney (1995), Mahoney and Pandian (1992), Majumdar (1998), Makadok (2001), Montgomery and Hariharan (1991), Montgomery and Wernerfelt (1988), Mosakowski (1993), Peteraf 
(1993), Robins and Wiersema (1995), Rumelt (1984, 1987), Sharma and Kesner (1996), Teece, Pisano and Shuen (1997), Wernerfelt (1984), Wernerfelt and Montgomery (1988). For a recent survey of the resource-based literature with particular attention to Penrose (1959), see Kor and Mahoney (2000). For a recent paper connecting resource-based theory and property rights theory, see Kim and Mahoney (2002).

4. Such bundles are also the source of potential value creation because such relation-specific assets generate quasi rents (Mahoney, 1992b), or positive externalities due to complementary assets and co-specialization (Teece, 1986).

5. One implication of the GHM model's definition of ownership is that the model only explains why individuals own assets but does not explain why firms own assets (Holmstrom, 1999).

6. A well sunk into any point in the pool tends to draw crude oil from across the whole reservoir deposit as petroleum flows, albeit slowly, to the region of reduced pressure. This geological fact means that if different economic parties have rights to draw from a single reservoir pool, there is a tendency toward rapid oil extraction. All of this is exacerbated by the possibility of sinking a well on one piece of property but drilling on an angle so that it hits the petroleum deposit under another's land. The results can be disastrous-Iraq's anger about Kuwait's alleged over-pumping and poaching in oil fields straddling the two nations' border was a major element leading to the Persian Gulf War of 1990-1991 (Milgrom and Roberts, 1992, p. 296).

7. In the state of New Mexico, after it added a compulsory unitization statute in 1977, production increased by 280 million barrels of oil from 33 statutory unitizations in a span of 20 years (Oil and Gas Journal, May 5, 1997). Using the experience of New Mexico to project effects of such a statute in Texas, it was predicted that 165 state-assisted (compulsory) unitizations would yield 1.4 billion barrels of oil over 20 years (Oil and Gas Journal, May 5, 1997). To put this figure in perspective, estimated production of crude oil for 1999 in the United States was approximately 1.95 billion barrels (U.S. Dept. of Energy, 2000). Just in the state of Texas, in 2000, approximately 400 million barrels were produced (Railroad Commission of Texas, 2001).

8. A classic paper on the common-pool problem (of which the case of the lack of oil field unitization in the United States and consequent over-drilling is an example) is Hardin's (1968) 'tragedy of the commons' where there is over-utilization of resources. For a modern game-theoretic treatment, see Ostrom et al. (1994).

9. Oil field unitization is preferred to outright consolidation by acquisition for at least two reasons: first, antitrust issues block acquisitions (and in some cases, unitization can be regulated by antitrust authorities); second, oil firms only lease the mineral rights from landowners, implying that there are shared property rights involved that complicate any outright transfer of ownership rights.

10. Past sunk cost commitments can constrain present viable options. Concerning governance, Argyres and Liebeskind (1999) use the term 'governance inseparability' to describe how a firm's boundary choices can be shaped by previous commitments.

11. Recent developments in the property rights literature in the tradition of the GHM model are closer to agency theory to the extent that the optimal design of contractual incentives is contemplated. However, the GHM model is in an incomplete contract setting and emphasizes a comparative assessment in that there are two (imperfect) alternatives available: common ownership and separate ownership, where there are important control properties inherent in ownership.

\section{REFERENCES}

Afuah A. 2000. How much do your co-opetitors' capabilities matter in the face of technological change? Strategic Management Journal 21: 387-404.

Afuah A. 2002. Mapping technological capabilities into product markets and competitive advantage: the case of cholesterol drugs. Strategic Management Journal 23: $171-179$.

Aghion P, Bolton P. 1992. An 'incomplete contracts' approach to financial contracting. Review of Economic Studies 59: 473-494.

Aghion P, Dewatripont M, Rey P. 1994. Renegotiations design with unverifiable information. Econometrica 62: 257-282.

Aghion P, Tirole J. 1994. On the management of innovation. Quarterly Journal of Economics 109: 1185-1209.

Aghion P, Tirole J. 1997. Formal and real authority in organizations. Journal of Political Economy 105: $1-29$.

Alchian AA. 1965. Some economics of property rights. Il Politico 30: 816-829. (reprinted in Economic Forces at Work. Alchian AA (ed.). 1977. Liberty Fund: Indianapolis; 127-149).

Alchian AA. 1969. Corporate management and property rights. In Economic Policy and Regulation of Corporate Securities, Manne HG (ed.). American Enterprise Institute for Public Policy Research: Washington DC; 337-360.

Alchian AA, Demsetz H. 1972. Production, information costs and economic organization. American Economic Review 62: 777-795.

Alchian AA, Demsetz H. 1973. The property right paradigm. Journal of Economic History 33: 16-27.

Alston LJ, Eggertsson T, North DC. 1996. Empirical Studies in Institutional Change. Cambridge University Press: Cambridge.

Alston LJ, Libecap GD, Mueller B. 1999. Titles, Conflict, and Land Use: The Development of Property Rights and Land Reform on the Brazilian Amazon Frontier. University of Michigan Press: Ann Arbor. 
Amit RH, Schoemaker PJH. 1993. Strategic assets and organizational rent. Strategic Management Journal 14: 33-46.

Anderson TL, Hill PJ. 1975. The evolution of property rights: a study of the American West. Journal of Law and Economics 18: 163-179.

Argyres NS. 1996. Evidence on the role of firm capabilities in vertical integration decisions. Strategic Management Journal 17: 129-150.

Argyres NS, Liebeskind JP. 1998. Privatizing the intellectual commons: universities and the commercialization of biotechnology. Journal of Economic Behavior and Organization 35: 427-454.

Argyres NS, Liebeskind JP. 1999. Contractual commitments, bargaining power and governance inseparability: incorporating history into transaction cost theory. Academy of Management Review 24: 49-63.

Athey S, Roberts J. 2001. Organization design: decision rights and incentive contracts. American Economic Review 91: 200-205.

Bajari P, Tadelis S. 2001. Incentives versus transaction costs: a theory of procurement contracts. Rand Journal of Economics 32: 387-407.

Baker G, Gibbons R, Murphy KJ. 1994. Subjective performance measures in optimal incentive contracts. Quarterly Journal of Economics 109: 1125-1156.

Baker G, Gibbons R, Murphy KJ. 1999. Informal authority in organizations. Journal of Law, Economics, and Organization 15: 56-73.

Baker G, Gibbons R, Murphy KJ. 2001. Bringing the market inside the firm? American Economic Review 91: 212-218.

Baker G, Gibbons R, Murphy KJ. 2002. Relational contracts and the theory of the firm. Quarterly Journal of Economics 117: 39-84.

Bakos JY, Nault B. 1997. Ownership and investment in electronic networks. Information Systems Research 8: 321-341.

Barney J. 1986. Strategic factor markets: expectations, luck and business strategy. Management Science 42: 1231-1241.

Barney J. 1991. Firm resources and sustained competitive advantage. Journal of Management 17: 99-120.

Barney JB, Ouchi WG. 1986. Organizational Economics. San Francisco: Jossey-Bass.

Barzel Y. 1982. Measurement cost and the organization of markets. Journal of Law and Economics 25: 27-48.

Barzel Y. 1997. Economic Analysis of Property Rights (2nd edn). Cambridge University Press: Cambridge.

Bernheim D, Whinston M. 1998. Incomplete contracts and strategic ambiguity. American Economic Review 88: $902-932$.

Bolton P, Scharfstein DS. 1998. Corporate finance, the theory of firms, and organizations. Journal of Economic Perspectives 12: 95-114.

Bolton P, Whinston MD. 1993. Incomplete contracts, vertical integration and supply assurance. Review of Economic Studies 60: 121-148.

Braguinsky S. 1999. Enforcement of property rights during the Russian transition: problems and approaches to a new liberal solution. Journal of Legal Studies 28: 515-532.
Brush TW, Artz KW. 1999. Toward a contingent resource-based theory: the impact of information asymmetry on the value of capabilities in veterinary medicine. Strategic Management Journal 20: 223-250.

Brynjolfsson E. 1994. Information assets, technology, and organization. Management Science 40: 1645-1662.

Carroll GR, Spiller PT, Teece DJ. 1999. Transaction cost economics: its influence on organizational theory, strategic management, and political economy. In Firms, Markets, and Hierarchies: the Transaction Cost Economics Perspective, Carroll GR, Teece DJ (eds). Oxford University Press: New York; 60-88.

Chang SJ. 1996. An evolutionary perspective on diversification and corporate restructuring: entry, exit, and economic performance during 1981-1989. Strategic Management Journal 17: 587-611.

Chatterjee S, Wernerfelt B. 1991. The link between resources and type of diversification: theory and practice. Strategic Management Journal 12: 33-48.

Cheung SNS. 1968. Private property rights and sharecropping. Journal of Political Economy 76: 1107-1122.

Cheung SNS. 1969. The Theory of Share Tenancy. University of Chicago Press: Chicago.

Cheung SNS. 1970. The structure of contract and the theory of a non-exclusive resource. Journal of Law and Economics 13: 49-70.

Cheung SNS. 1983. The contractual nature of the firm. Journal of Law and Economics 26: 1-21.

Chi T. 1994. Trading in strategic resources: necessary conditions, transaction cost problems, and choice of exchange partners. Strategic Management Journal 15: 271-290.

Chi T, Roehl TW. 1997. The structuring of interfirm exchanges in business know-how. Evidence from international collaborative ventures. Managerial and Decision Economics 18: 279-294.

Chiu YS. 1998. Noncooperative bargaining, hostages and optimal asset ownership. American Economic Review 88: 882-901.

Coase RH. 1937. The nature of the firm. Economica 4: 386-405.

Coase RH. 1959. The Federal Communications Commission. Journal of Law and Economics 2: 1-40.

Coase RH. 1960. The problem of social cost. Journal of Law and Economics 3: 1-44.

Coff RW. 1997. Human assets and managerial dilemmas: coping with hazards on the road to resourcebased theory. Academy of Management Review 22: 374-402.

Conner KR. 1991. An historical comparison of resource-based theory and five schools of thought within industrial organization economics: do we have a new theory of the firm? Journal of Management 17: 121-154.

Davis LE, North DC. 1971. Institutional Change and American Economic Growth. Cambridge University Press: Cambridge.

De Meza D, Lockwood B. 1998. Does asset ownership always motivate managers? Outside options and the property rights theory of the firm. Quarterly Journal of Economics 113: 361-386. 
Demsetz H. 1964. The exchange and enforcement of property rights. Journal of Law and Economics 3: 11-26.

Demsetz H. 1966. Some aspects of property rights. Journal of Law and Economics 9: 61-70.

Demsetz H. 1967. Towards a theory of property rights. American Economic Review 57: 347-359.

Demsetz H. 1969. Information and efficiency: another viewpoint. Journal of Law and Economics 12: 1-22.

Demsetz H. 1988. Ownership, Control, and the Firm. Oxford University Press: New York.

Demsetz H. 1998. Review: Oliver Hart's firms, contracts, and financial structure. Journal of Political Economy 106: 446-452.

Dierickx I, Cool K. 1989. Asset accumulation and sustainability of competitive advantage. Management Science 35: 1504-1511.

Eggertsson T. 1990. Economic Behavior and Institutions. Cambridge University Press: New York.

Eisenhardt KM. 1989. Agency theory: an assessment and review. Academy of Management Review 14: 57-74.

Eisenhardt KM, Martin JA. 2000. Dynamic capabilities: what are they? Strategic Management Journal 21: 1105-1121.

Eisenhardt KM, Schoonhoven CB. 1996. Resourcebased view of strategic alliance formation: strategic and social effects in entrepreneurial firms. Organization Science 7: 136-148.

Fama EF. 1980. Agency problems and the theory of the firm. Journal of Political Economy 88: 288-307.

Fama EF, Jensen MC. 1983. Separation of ownership and control. Journal of Law and Economics 26: 301-325.

Farjoun M. 1994. Beyond industry boundaries: human expertise, diversification and resource-related industry groups. Organization Science 5: 185-199.

Farjoun M. 1998. The independent and joint effects of the skill and physical bases of relatedness in diversification. Strategic Management Journal 19: 611-630.

Foss NJ. 1996. Knowledge-based approaches to the theory of the firm: some critical comments. Organization Science 7: 477-501.

Foss K, Foss NJ. 1999. Understanding ownership: residual rights of control and appropriable control rights. Working Paper, Copenhagen Business School, Copenhagen, Denmark.

Foss K, Foss NJ. 2001. Assets, attributes, and ownership. International Journal of Economics of Business 8: 19-37.

Furubotn EG. 2001. The new institutional economics and the theory of the firm. Journal of Economic Behavior and Organization 45: 133-153.

Furubotn EG, Pejovich S. 1972. Property rights and economic theory: a survey of recent literature. Journal of Economic Literature 10: 1137-1162.

Furubotn EG, Pejovich NJ. 1973. Property rights, economic decentralization and the evolution of the Yugoslav firm, 1965-1972. Journal of Law and Economics 16: 273-302.

Furubotn EG, Pejovich S. 1974. The Economics of Property Rights. Ballinger: Cambridge.
Galunic DC, Eisenhardt KM. 2001. Architectural innovation and modular corporate forms. Academy of Management Journal 44: 1229-1249.

Gibbons R. 1998. Incentives in organizations. Journal of Economic Perspectives 12: 115-132.

Goldberg VP. 1974. Institutional change and the quasi-invisible hand. Journal of Law and Economics 17: 461-492.

Grant RM. 1996. Toward a knowledge-based theory of the firm. Strategic Management Journal 17(Winter): $109-122$.

Grossman S, Hart O. 1986. The costs and benefits of ownership: a theory of vertical integration and lateral integration. Journal of Political Economy 94: 691-719.

Grossman HI. 2001. The creation of effective property rights. American Economic Review 91: 347-352.

Hackett D. 1993. Incomplete contracting: a laboratory experimental analysis. Economic Inquiry 31: 274-297.

Hardin G. 1968. The tragedy of the commons. Science 162: $1243-1248$.

Hart O. 1988. Incomplete contracts and the theory of the firm. Journal of Law, Economics and Organization 4: 119-139.

Hart O. 1995. Firms, Contracts, and Financial Structure. Clarendon Press: Oxford.

Hart O, Moore J. 1988. Incomplete contracts and renegotiation. Econometrica 56: 755-785.

Hart O, Moore J. 1990. Property rights and the nature of the firm. Journal of Political Economy 98: 1119-1158.

Hart O, Moore J. 1999. Foundation of incomplete contracts. Review of Economic Studies 66: 115-138.

Helfat CE. 1994. Firm-specificity in corporate applied R\&D. Organization Science 5: 173-184.

Helfat CE. 1997. Know-how and asset complementarity and dynamic capability accumulation: the case of R\&D. Strategic Management Journal 18: 339-360.

Helfat CE, Raubitschek RS. 2000. Product sequencing: co-evolution of knowledge, capabilities and products. Strategic Management Journal 21: 961-979.

Hellmann T. 1998. The allocation of control rights in venture capital markets. Rand Journal of Economics 29: $57-76$.

Henderson R. 1994. The evolution of integrative capability: innovation in cardiovascular drug discovery. Industrial and Corporate Change 3: 607-630.

Henderson R, Cockburn I. 1994. Measuring competence? Exploring firm effects in pharmaceutical research. Strategic Management Journal 15(Winter): 63-84.

Hennart J. 1993. Explaining the 'swollen middle': why most transactions are a mix of market and hierarchy. Organization Science 4: 529-547.

Holmstrom B. 1979. Moral hazard and observability. Bell Journal of Economics 10: 74-91.

Holmstrom B. 1982. Moral hazard in teams. Bell Journal of Economics 13: 324-340.

Holmstrom B. 1999. The firm as a subeconomy. Journal of Law, Economics and Organization 15: 74-102.

Holmstrom B, Milgrom B. 1991. Multitask principalagent analyses: incentive contracts, asset ownership 
and job design. Journal of Law, Economics and Organization 7(Special issue): 24-52.

Holmstrom B, Milgrom B. 1994. The firm as an incentive system. American Economic Review 84: 972-991.

Holmstrom B, Roberts J. 1998. The boundaries of the firm. Journal of Economic Perspectives 12: 73-94.

Hoopes DG, Postrel S. 1999. Shared knowledge, 'glitches,' and product development performance. Strategic Management Journal 20: 837-865.

James HS. 2000. Separating contract from governance. Managerial and Decision Economics 21: 47-61.

Jehiel P, Moldovanu B. 1999. Resale markets and the assignment of property rights. Review of Economic Studies 66: 971-986.

Jensen MC. 1983. Organization theory and methodology. Accounting Review 56: 319-338.

Jensen MC, Meckling W. 1976. Theory of the firm: managerial behavior, agency costs, and ownership structure. Journal of Financial Economics 3: 305-360.

Jensen MC, Meckling W. 1979. Rights and production functions: an application to labor-managed firms and co-determination. Journal of Business 52: 469-506.

Jones GR. 1983. Transaction costs, property rights, and organizational culture: an exchange perspective. Administrative Science Quarterly 28: 454-467.

Kim J, Mahoney JT. 2002. Resource-based and property rights perspectives on value creation: the case of oil field unitization. Managerial and Decision Economics 23: 225-245.

Kor YY, Mahoney JT. 2000. Penrose's resource-based approach: the process and product of research creativity. Journal of Management Studies 37: 109-139.

Kreps DM. 1990. Corporate culture and economic theory. In Perspectives on Political Economy, Alt JE, Shepsle KA (eds). Cambridge University Press: Cambridge; $90-143$.

Leonard-Barton D. 1992. Core capabilities and core rigidities: a paradox in managing new product development. Strategic Management Journal 13: 111-125.

Libecap GD. 1986. Property rights in economic history: implications for research. Explorations in Economic History 23: 227-252.

Libecap GD. 1989. Contracting for Property Rights. Cambridge University Press: New York.

Libecap GD. 1998. Unitization. In New Palgrave Dictionary of Law and Economics, Newman P (ed.). Oxford University Press: New York; 641-644.

Libecap GD, Wiggins SN. 1984. Contractual responses to the common pool: prorationing of crude oil production. American Economic Review 74: 87-98.

Libecap GD, Wiggins SN. 1985. The influence of private contractual failure on regulation: the case of oil field unitization. Journal of Political Economy 93: 690-714.

Libecap GD, Smith JL. 1999. The self-enforcing provisions of oil and gas unit operating agreements: theory and evidence. Journal of Law, Economics and Organization 15: 526-548.

Libecap GD, Smith JL. 2001. Regulatory remedies to the common pool: the limits to oil field unitization. Energy Journal 22: 1-26.
Liebeskind JP. 1996. Knowledge, strategy, and the theory of the firm. Strategic Management Journal 17(Winter): 93-107.

Lippman SA, Rumelt RP. 1982. Uncertain imitability: an analysis of interfirm differences in efficiency under competition. Bell Journal of Economics 13: 418-438.

Lueck D. 1995. The rule of first possession and the design of the law. Journal of Law and Economics 38: 393-436.

MacLeod WB, Malcomson JM. 1993. Investments, holdup, and the form of market contacts. American Economic Review 83: 811-837.

Mahoney JT. 1992a. Organizational economics within the conversation of strategic management. In Advances in Strategic Management, Shrivastava P, Huff A, Dutton J (eds); 8: 103-155.

Mahoney JT. 1992b. The choice of organizational form: vertical financial ownership versus other methods of vertical integration. Strategic Management Journal 13: $559-584$.

Mahoney JT. 1995. The management of resources and the resource of management. Journal of Business Research 33: 99-101.

Mahoney JT, Pandian JR. 1992. The resource-based view within the conversation of strategic management. Strategic Management Journal 13: 363-380.

Majumdar SK. 1998. On the utilization of resources: perspectives on the U.S. telecommunications industry. Strategic Management Journal 19: 809-831.

Makadok R. 2001. Toward a synthesis of resourcebased and dynamic capability views of rent creation. Strategic Management Journal 22: 387-401.

Maskin E, Moore J. 1999. Implementation and renegotiation. Review of Economic Studies 66: 39-56.

Maskin E, Tirole J. 1999a. Unforeseen contingencies and incomplete contracts. Review of Economic Studies 66: 83-114.

Maskin E, Tirole J. 1999b. Two remarks on property rights. Review of Economic Studies 66: 139-149.

McDonald SL. 1971. Petroleum Conservation in the United States: an Economic Analysis. Resources for the Future: Baltimore.

Michael SC. 2000. Investments to create bargaining power: the case of franchising. Strategic Management Journal 21: 497-514.

Milgrom P, Roberts J. 1992. Economics, Organization and Management. Prentice-Hall: Englewood Cliffs, NJ.

Miller D, Shamsie J. 1996. The resource-based view of the firm in two environments: the Hollywood film studios from 1936 to 1965. Academy of Management Journal 39: 519-543.

Miller GJ. 1992. Managerial Dilemmas: The Political Economy of Hierarchy. Cambridge University Press: Cambridge.

Montgomery CA, Hariharan S. 1991. Diversified entry by established firms. Journal of Economic Behavior and Organization 15: 71-89.

Montgomery CA, Wernerfelt B. 1988. Diversification, Ricardian rents, and Tobin's q. Rand Journal of Economics 19: 623-632. 
Mosakowski E. 1993. A resource-based perspective on the dynamic strategy-performance relationship: an empirical examination of the focus and differentiation strategies in entrepreneurial firms. Journal of Management 19: 819-839.

Mullainathan S, Scharfstein D. 2001. Do firm boundaries matter? American Economic Review 91: 184-188.

Muller HM, Warneryd K. 2001. Inside versus outside ownership: a political theory of the firm. Rand Journal of Economics 32: 527-541.

Noldeke G, Schmidt K. 1995. Option contracts and renegotiation: a solution to the hold-up problem. Rand Journal of Economics 26: 163-179.

North DC. 1981. Structure and Change in Economic History. Norton: New York.

North DC. 1990. Institutions, Institutional Change and Economic Performance. Cambridge University Press: New York.

Ostrom E, Gardner R, Walker J. 1994. Rules, Games and Common-Pool Resources. University of Michigan Press: Ann Arbor.

Oxley JE. 1999. Institutional environment and the mechanism of governance: the impact of intellectual property protection on the structure of inter-firm alliances. Journal of Economic Behavior and Organization 38: 283-309.

Pejovich S. 1982. Karl Marx, property rights school and the process of social change. Kyklos 35: 383-407.

Pejovich S. 1995. Economic Analysis of Institutions and Systems. Kluwer Academic: Boston.

Penrose ET. 1959. The Theory of the Growth of the Firm. Wiley: New York.

Peteraf M. 1993. The cornerstones of competitive advantage: a resource-based view. Strategic Management Journal 14: 179-191.

Railroad Commission of Texas. 2001. Texas Monthly Oil and Gas Production (1995-2000).http://www.rrc.state.tx. us/divisions/og/information-data/stats/ogismcon.html.

Rajan R, Zingales L. 1998. Power in a theory of the firm. Quarterly Journal of Economics 113: 387-432.

Rajan R, Zingales L. 2001. The firm as a dedicated hierarchy: a theory of the origins and growth of the firm. Quarterly Journal of Economics 116: 805-851.

Robins JA, Wiersema MF. 1995. A resource-based approach to the multibusiness firm: empirical analysis of portfolio interrelationships and corporate financial performance. Strategic Management Journal 16: 277-299.

Rumelt RP. 1984. Toward a strategic theory of the firm. In Competitive Strategic Management, Lamb R (ed.). Prentice Hall: Englewood Cliffs, NJ; 556-570.

Rumelt RP. 1987. Theory, strategy, and entrepreneurship. In The Competitive Challenge, Teece D (ed.). Ballinger: Cambridge; $137-158$.

Rumelt RP, Schendel DE, Teece DJ. 1994. Fundamental Issues in Strategy: A Research Agenda. Harvard Business School Press: Boston.
Segal I. 1999. A theory of incomplete contracts. Review of Economic Studies 66: 57-82.

Sharma A, Kesner IF. 1996. Diversifying entry: some ex ante explanations for post entry survival and growth. Academy of Management Journal 39: 635-677.

Smith JL. 1987. The common pool, bargaining, and the rule of capture. Economic Inquiry 25: 631-644.

Teece DJ. 1982. Towards an economic theory of the multi-product firm. Journal of Economic Behavior and Organization 3: 39-63.

Teece DJ. 1986. Profiting from technological innovation: implications for integration, collaboration, licensing and public policy. Research Policy 15: 285-305.

Teece DJ, Pisano G, Shuen A. 1997. Dynamic capabilities and strategic management. Strategic Management Journal 18: 509-533.

Tiratsoo EN. 1976. Oilfields of the World (2nd edn). Scientific Press, Ltd.: Beaconsfield.

Tirole J. 1999. Incomplete contracts: where do we stand? Econometrica 67: 741-781.

U.S. Department of Energy. 2000. U.S. crude oil, natural gas, and natural gas liquids reserves. 1999 Annual Report, Energy Information Administration, Office of Oil and Gas, U.S. Department of Energy: Washington DC.

Weaver JL. 1986. Unitization of Oil and Gas Fields in Texas: A Study of Legislative, Administrative, and Judicial Policies. Resources for the Future, Inc.: Washington DC.

Wernerfelt B. 1984. A resource-based view of the firm. Strategic Management Journal 5: 171-180.

Wernerfelt B, Montgomery CA. 1988. Tobin's q and the importance of focus in firm performance. American Economic Review 78: 246-250.

Whinston MD. 2001. Assessing the property rights and transaction cost theories of firm scope. American Economic Review 91: 184-188.

Wiggins SN, Libecap GD. 1985. Oil field unitization: contractual failure in the presence of imperfect information. American Economic Review 75: 368-385.

Williamson OE. 1975. Markets and Hierarchies: Analysis and Antitrust Implications. The Free Press: New York.

Williamson OE. 1985. The Economic Institutions of Capitalism: Firms, Markets, Relational Contracting. The Free Press: New York.

Williamson OE. 1991. Comparative economic organization: the analysis of discrete structural alternatives. Administrative Science Quarterly 36: 269-296.

Williamson OE. 1996. The Mechanisms of Governance. Oxford University Press: New York.

Williamson OE. 2000. The new institutional economics: taking stock and looking ahead. Journal of Economic Literature 38: 595-613.

Yang X, Ng NK. 1995. Theory of the firm and structure of residual rights. Journal of Economic Behavior and Organization 26: 107-128. 